Wright State University

CORE Scholar

Physics Faculty Publications

Physics

$12-1968$

\title{
Measurement of Electron Spin-Lattice Relaxation Times Using Ordinary EPR Spectrometers
}

David C. Look

Wright State University - Main Campus, david.look@wright.edu

Donald R. Locker

Follow this and additional works at: https://corescholar.libraries.wright.edu/physics

Part of the Physics Commons

\section{Repository Citation}

Look, D. C., \& Locker, D. R. (1968). Measurement of Electron Spin-Lattice Relaxation Times Using Ordinary EPR Spectrometers. Journal of Applied Physics, 39 (13), 6119-6120.

https://corescholar.libraries.wright.edu/physics/605

This Article is brought to you for free and open access by the Physics at CORE Scholar. It has been accepted for inclusion in Physics Faculty Publications by an authorized administrator of CORE Scholar. For more information, please contact library-corescholar@wright.edu. 


\section{AIP Applited Physics}

\section{Measurement of Electron SpinLattice Relaxation Times using Ordinary EPR Spectrometers}

D. R. Locker and D. C. Look

Citation: J. Appl. Phys. 39, 6119 (1968); doi: 10.1063/1.1656138

View online: http://dx.doi.org/10.1063/1.1656138

View Table of Contents: http://jap.aip.org/resource/1/JAPIAU/v39/i13

Published by the American Institute of Physics.

\section{Additional information on J. Appl. Phys.}

Journal Homepage: http://jap.aip.org/

Journal Information: http://jap.aip.org/about/about_the_journal

Top downloads: http://jap.aip.org/features/most_downloaded

Information for Authors: http://jap.aip.org/authors

\section{ADVERTISEMENT}

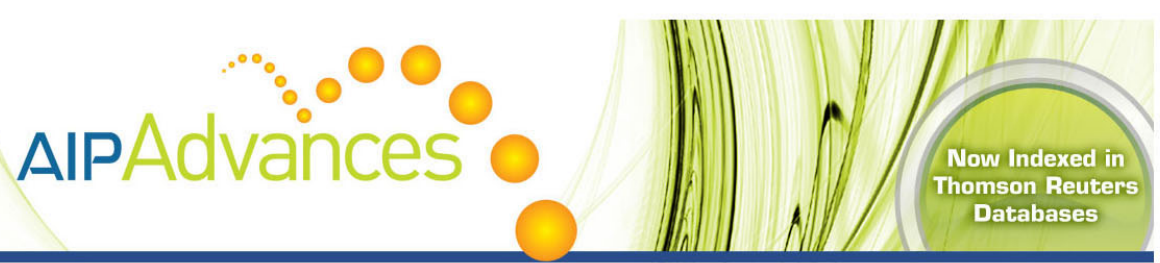

\section{Explore AIP's open access journal: •Rapid publication \\ - Article-level metrics \\ - Post-publication rating and commenting}


axis of the sample. The angle between easy axis and geometric axis can be varied under large limits by annealing. Thus, the second sentence in the definition of the Procopiu effect must be formulated as follows:

Under such conditions the search coil produces a signal whose frequency: (1) is twice the frequency of the sinusoidal alternating current in the wire, if the easy axis coincides with the geometric axis of the sample and if the sample does not perform magnetostrictively induced torsional or longitudinal oscillations, and (2) equalizes the frequency of the sinusoidal alternating current in the wire if the easy axis does not coincide with the geometric axis of the sample, $\mathrm{H}_{y}$ is smaller than $\mathrm{H}_{\psi}$, and the sample does not perform magnetostrictively induced torsional and longitudinal oscillations.

If the sample performs magnetostrictively induced torsional and longitudinal oscillations, there are a great variety of possible cases for the form and frequency of the electromotive force induced in the search coil.

1 R. Skorski and A. Duracz, J. Appl. Phys. 36, 511 (1965).

${ }^{2}$ A. B. Kaufman, J. Appl. Phys, 36, 3928 (1965).

${ }^{3}$ E. C. Stoner and E. P. Wohlfarth, Phil. Trans. Roy. Soc. London 240, 599 (1948).

4 B. F. Rothenstein, A. Policec, C. Anghel, and M. Lupulescu, Phys. Status Solidi 19, 613 (1967).

5 I. R. Smith and K. J. Overshott, Brit. J. Appl. Phys. 16, 1247 (1965).

6 I. R. Smith, B. K. Gazey, and J. L. Black, J. Sci. Instr. 43, 251 (1966)

7 B. F. Rothenstein, A. Policec, M. Lupulescu, and C. Anghel, Phys. Status Solidi 21, 601 (1967).

B. F. Rothenstein and A. Policec, Compt. Rend. 265, 789 (1967).

\section{Measurement of Electron Spin-Lattice Relaxation Times using Ordinary EPR Spectrometers}

\author{
D. R. LOCKER AND D. C. LOOK \\ Aerospace Research Laboratories, Wright-Patterson Air \\ Force Base, Ohio 45433 \\ (Received 8 August 1968)
}

The purpose of this letter is to show that by a rather simple low-cost modification to almost any existing EPR spectrometer one can make precise $T_{1}$ measurements over a wide range of values. Ordinarily, using $\mathrm{cw}$ microwave techniques, good precision $(\sim 10 \%)$ can only be obtained for $T_{1}$ long enough to allow use of the transient recovery method, that is, to maintain a resonant $H_{0}$ long enough to saturate the line, move off resonance for an interval $r$, and scan the resonance, observing the recovered magnetization. For $T_{1}$ less than, say, a few seconds, one usually resorts to progressive saturation, and sacrifices precision or effort required, or both. This difficulty has practically limited detailed cw EPR $T_{1}$ investigations to the slow relaxing centers which may be found in materials at quite low temperatures. Of course there are several methods using pulsed-microwave techniques which give precise results in both the cases of short and long times; however, it is appealing that an investigator who has just discovered a center may also be able to measure $T_{1}$ vs temperature

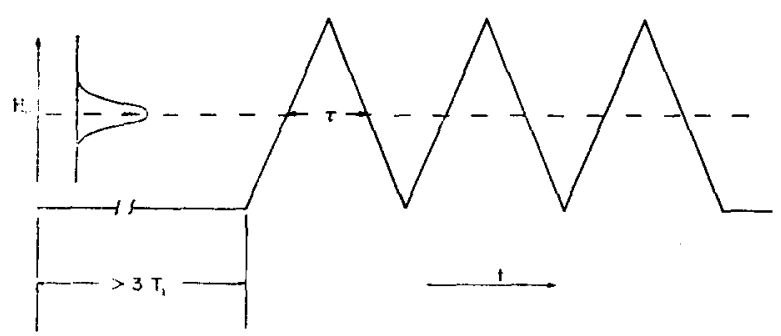

Frc. 1. Time dependence of magnetic field during tone-burst operation.

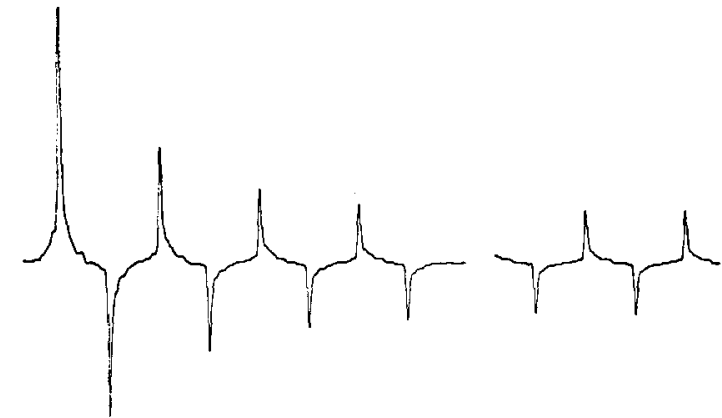

FIG. 2. Response of $\mathrm{MgO}: \mathrm{Cr}^{3+}$ resonance at $9.6 \mathrm{GHz}$ to tone-burst modulation, $\tau=0.5 \sec (f=20 \mathrm{~Hz})$. Second trace is free-run response. See text for details.

without introducing another type of spectrometer. Additionally, it is not uncommon to find laboratories with a cw capability at two or three frequencies, and the new equipment that is needed to measure $T_{1}$ 's at one frequency is common to all.

The new method we use is a specific application, to EPR, of the tone-burst modulation scheme which the authors recently described for cw NMR. ${ }^{1}$ There are features which are common to both, but special attention will be given to the application at hand. Briefly, one assembles a system which will give the field versus time characteristic, at the region of the sample, depicted in Fig. 1. We connect a Wavetek model 111 oscillator to the input of a General Radio model 1396 tone-burst generator. The output is then fed to a dc linear, zero-damping amplifier (a fast programmable power supply with current feedback) which drives sweep coils at the cavity. The microwave magnetic field $H_{1}$ is adjusted to give a partial saturation on passing through resonance. After the centers have reached equilibrium off resonance, the field is swept back and forth through resonance causing the magnetization to be reduced by the partial saturation of each pass until an equilibrium is reached with recovery between passes. Such a sequence is shown in Fig. 2 for $\mathrm{MgO}: \mathrm{Cr}^{3+}$ at $4.2^{\circ}$ using a Varian Associates model V-4531 cavity with an internal helium Dewar. The reversed peaks are not caused by reversed magnetization, but by scan reversal in conjunction with 100 $\mathrm{kHz}$ phase-sensitive detection; furthermore, integration results from the narrow bandwidth of the amplifier-phase-detector combination. To calculate $T_{1}$ the procedure is as follows:

(1) Since the peak amplitudes are proportional to the magnetization, designate the amplitudes $M_{0}, M_{1}, M_{2}, \cdots$.

(2) Plot $\log \left(M_{n}-M_{\infty}\right)$ vs $n,(n=0,1,2, \cdots)$ and determine the slope $S . M_{\infty}$ is usually determined by switching from toneburst to the free-run mode.

(3) Assuming the usual nonadiabatic case, calculate $T_{1}$ from

$$
\tau / T_{1}=\ln \left[1+M_{\infty} /\left(M_{0}-M_{\infty}\right)\right] /\left[1+e^{s} M_{\infty} /\left(M_{0}-M_{\infty}\right)\right] \text {, }
$$

where $\tau$ is the interval between successive peaks, which is onehalf of the modulation period. A best value for $M_{0}-M_{\infty}$ is taken from the graph intercept. A derivation of this result is given in Ref. 1.

Now we shall briefly discuss the lower limiting $T_{1}$ for common types of $\mathrm{cw}$ EPR apparatus. It should be remembered that in each case the limitation might be due to the cavity's shielding of the tone-burst modulation. Currently, possibly the most commonly encountered cavity type, in the field, is one with highfrequency $(100 \mathrm{kHz})$ modulation coils outside of the cavity lining itself, but within the heavier, more shielding framework. In this type, the low-frequency tone-burst is impressed on the same coils through an isolating network. This network causes a fed-back current amplifier to become unstable unless frequency limiting is employed. Thus faithful modulation can be achieved only to a few hundred hertz which limits $T_{1}$ to about $10^{-2} \mathrm{sec}$. 


\begin{tabular}{|c|c|c|c|c|}
\hline $\begin{array}{l}\text { CENTER AND } \\
\text { IEMPERATURE }\end{array}$ & & $\begin{array}{l}T_{1} \text { MEASURED } \\
\text { BY TONE-BURST }\end{array}$ & $\begin{array}{l}\text { VAL } \\
\text { LITE }\end{array}$ & $\begin{array}{l}\text { JE FROM } \\
\text { RATURE }\end{array}$ \\
\hline $\mathrm{MgO}: \mathrm{Cr}^{* *}$ & $\begin{array}{l}1.4^{\circ} \mathrm{K} \\
2.1^{\circ} \\
4.2^{\circ}\end{array}$ & $\begin{array}{l}0.66 \text { sec. } \\
0.46 \\
0.25\end{array}$ & $\begin{array}{l}0.74 \\
0.55 \\
0.30\end{array}$ & $\begin{array}{l}\text { sec. } \\
\text { REF. } 2\end{array}$ \\
\hline $\begin{array}{l}\text { CORNING } 7943 \\
\text { FUSED SILICA } \\
E^{\prime} \text { CENTER }\end{array}$ & $4.2^{\circ}$ & 19. & 18. & REF. 3 \\
\hline $\mathrm{ThO}_{\mathrm{E}}: \mathrm{Yb}_{\mathrm{B}} \mathrm{z}+1 \%$ & $4.2^{\circ}$ & 0.031 & 0.04 & REF. 4 \\
\hline
\end{tabular}

Again, using $100 \mathrm{kHz}$ modulation, but with a largely dielectric cavity, and with separate low-frequency coils, one is then limited only by the bandwidth of the detection system. Most such systems could be expected to measure $T_{1}$ 's as low as $10^{-3} \mathrm{sec}$.

The theoretical lower limitation on $T_{1}$ is due to the response time $(\sim Q / f)$ of the cavity being used. To get enough bandwidth, and without sacrificing sensitivity faster than $[1 / \Delta f]^{1 / 2}$, one may resort to superheterodyne detection. In this case, the only field modulation would be that of the tone-burst itself. With linear sweep amplifiers available today, one might approach $T_{1}=10^{-4}$ sec. However, by using high-speed sweep circuits, and with special attention to cavity-coil geometry, one might extend the range to under $10^{-5} \mathrm{sec}$.

Figure 3 is included to compare values obtained by the described method with those on the same centers given in the literature..$^{2-4}$

We would like to acknowledge the generosity of Dr. G. R. Wagner of the Westinghouse Research and Development Center, and Professor J. G. Castle of the University of Pittsburgh for providing the samples with measured relaxation times.

1 D. C. Look and D. R. Locker, Phys. Rev. Letters 20, 987 (1968).

2 J. G. Castle, Jr. and D. W. Feldman, Phys. Rev. 121, 1349 (1961)

${ }^{3}$ J. G. Castle, Jr. and D. W. Feldman, J. Appl. Phys. 36, 124 (1965).

4 G. R. Wagner (private communication).

\section{Laser Emission of a Neodymium Salt Dissolved in $\mathrm{POCl}_{3}$}

\author{
Erhard J. Schimitschek \\ Naval Electronics Laboratory Center, San Diego, California 92152 \\ (Received 22 April 1968)
}

As was shown by Heller, ${ }^{1}$ the ${ }^{4} F_{3 / 2} \rightarrow{ }^{4} I_{11 / 2}$ fluorescence of $\mathrm{Nd}^{3+}$ in solution is appreciable only in solvents with low vibrational

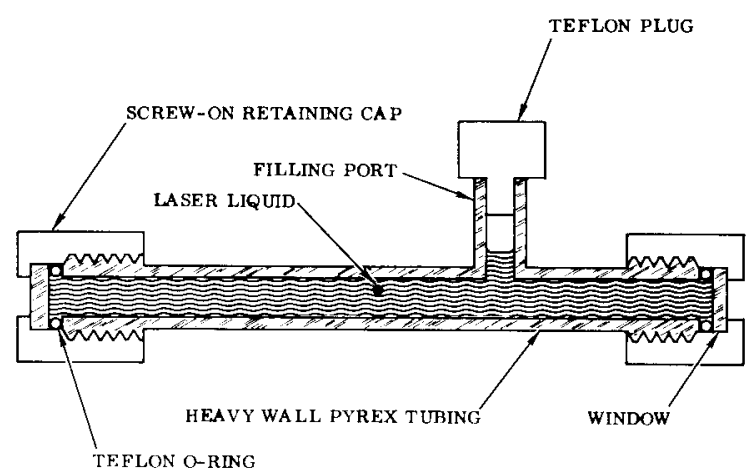

FIG. 1. Typical cell used in experiment. Screw-on retaining caps were made of Teflon or metal. The liquid was in contact only with Teflon and glass to prevent contamination. frequencies. $\mathrm{SeOCl}_{2}$ is one of those solvents and was originally used by Heller and Lempicki ${ }^{2}$ in the first inorganic liquid laser experiments.

We recently started to look for additional solvents to be used in this connection with the twofold aim to broaden the understanding of energy transfer in these media and also, eventually, to arrive at a solution which would be easier to handle than the toxic and corrosive $\mathrm{SeOCl}_{2}$.

The first solvent which we investigated and which led to successful laser emission was $\mathrm{POCl}_{3}$. Due to its lower dielectric constant 3 (13.9, compared to 46.2 for $\mathrm{SeOCl}_{2}$ ), $\mathrm{POCl}_{3}$ does not dissolve $\mathrm{Nd}_{2} \mathrm{O}_{3}$ or $\mathrm{NdCl}_{3}$. The only anhydrous neodymium salt we found to dissolve easily in $\mathrm{POCl}_{3}$ was $\mathrm{Nd}\left(\mathrm{ClO}_{4}\right)_{3}$. The anhydrous perchlorate was prepared from the hydrated salt by drying it at $155^{\circ} \mathrm{C}$ at reduced pressure as reported by Slavkina et al. ${ }^{4}$ The $\mathrm{Nd}\left(\mathrm{ClO}_{4}\right)_{3}$ dissolved in $\mathrm{POCl}_{3}$ shows the characteristic $\mathrm{Nd}^{3+}$ fluorescence, although the intensity is not as strong as would be expected from a solvent which has its highest vibrational frequency at $1300 \mathrm{~cm}^{-1}$. The fluorescence intensity increases drastically (about fifty times), however, when small amounts of a Lewis acid are added. We found $\mathrm{TiCl}_{4}$ most effective. Apparently, $\mathrm{Cl}^{-}$ions, originating from the autodissociation of the solvent, can quench the $\mathrm{Nd}^{3+}$ fluorescence unless they are captured by the acid to form compounds like $\mathrm{TiCl}_{6}{ }^{2-}$. Other Lewis acids

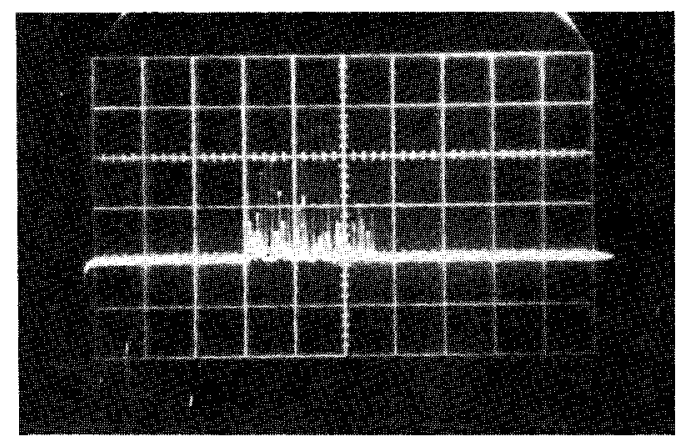

FIG. 2. Characteristic spike pattern from laser. Discharge energy is $200 \mathrm{~J}$. sweep time $200 \mu \mathrm{sec} / \mathrm{div}$.

can be used instead of $\mathrm{TiCl}_{4}$. For example, we also achieved laser action with $\mathrm{ZrCl}_{4}$ and $\mathrm{BBr}_{3}$.

A typical laser solution was prepared by dissolving the calculated amount of $\mathrm{Nd}\left(\mathrm{ClO}_{4}\right)_{3}$ in 20:1 mixture (by volume) of $\mathrm{POCl}_{3}$ and $\mathrm{TiCl}_{4}$ to give a $0.1 M$ solution. All manipulations should be carried out under a fume hood because of the corrosive nature of these chemicals. The solutions were filled into cells like to one shown in Fig. 1. The cells were placed in one of the laser heads described earlier. ${ }^{5}$ Since $\mathrm{POCl}_{3}$ and $\mathrm{TiCl}_{4}$ form an addition compound which absorbs strongly in the blue, the FX-45 water-cooled flashlamp was surrounded with a Corning No. 3530 tubular, yellow filter. This prevented unnecessary heating of the liquid.

External dielectric mirrors of different curvature and reflectivity were used for feedback. Antireflection coatings were applied to the cell windows. Output energies of $2.5 \mathrm{~J}$ were obtained with $600 \mathrm{~J}$ discharge energy. Threshold energies down to $30 \mathrm{~J}$ or less were measured, depending on the mirrors used. A typical spike pattern recorded with a PIN-10 diode is shown in Fig. 2. Above threshold, beam collimation and line narrowing were observed. The fluorescence line width of $200 \AA$ narrowed down to less than $4 \AA$ (limit of instrument). The output wavelength was measured to be $1.053 \mu$.

$Q$-spoiling and second-harmonic generation with ADP were readily performed with this laser. 